\title{
MUSCLE STRENGTH AND CAFFEINE SUPPLEMENTATION: ARE WE DOING MORE OF THE SAME?
}

\author{
FORÇA MUSCULARE SUPLEMENTAÇÃO DE CAFEÍNA: ESTAMOS FAZENDO MAIS DO MESMO? \\ FUERZA MUSCULAR Y SUPLEMENTACIÓN DE CAFEÍNA: ¿ESTAMOS HACIENDO MÁS DEL MISMO?
}

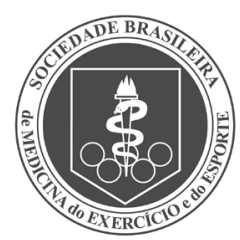

Review Article

ARTIGO DE REVISÃo ARtículo de REVISIÓN
Edgard de Melo Keene Von Koenig Soares

(Physical Education Professional)

Giliard Lago Garcia'

(Physical Education Professional)

Guilherme Eckhardt Molina'

(Physical Education Professional)

Keila Elizabeth Fontana'

(Physical Education Professional)

1. Universidade de Brasília, Faculdade de Educação Física, Laboratório de Fisiologia do Exercício, Brasília, DF, Brazil.

\section{Correspondence}

Edgard de Melo Keene Von Koenig Soares. Laboratório de Fisiologia do Exercício. Universidade de Brasília, Faculdade de Educação Física. Brasília, DF, Brazil. 70910-900 edgardsoares@gmail.com

\begin{abstract}
The purpose of this review was to examine in the current literature the advances made in terms of the effects of caffeine supplementation on maximum strength and its associated mechanisms since the publication of two important papers in 2010. Searches were carried out in the PubMed, Medline, Scielo and Web of Science databases for articles published after 2010. Sixteen studies were included based on inclusion and exclusion criteria. Five studies did not report changes in maximal voluntary strength (31.3\%). Four of them used isometric muscle contractions, although this may not be a key factor because five other studies also used isometric contractions and reported ergogenic effects. Furthermore, these four studies evaluated small muscle groups and volunteers were not accustomed to consuming caffeine. Caffeine produced ergogenic effects in eleven of the sixteen studies analyzed (68.8\%). None of the doses were clearly related to ergogenic effects; however, a dose of at least $3 \mathrm{mg} / \mathrm{kg}$ of caffeine is probably necessary. Caffeine ergogenicity was affected by various factors. There was a lack of standardized protocols and controls for intervening factors (e.g., circadian cycles and nutritional states), which could affect results. An ideal caffeine supplementation protocol that is useful for future research, athletes, and physical activity practitioners, has yet to be defined. A small advance made since 2010 involved a possible lack of gender difference; it would appear that caffeine supplementation affects men and women equally. Level of Evidence l; Systematic Review of Level I Studies.
\end{abstract}

Keywords: Performance-enhancing substances; Cytochrome P-450 CYP1 A2; Adenosine A2 receptor antagonists; Resistance training; Quadriceps muscle; Muscle contraction.

\section{RESUMO}

O objetivo desta revisão foi examinar na literatura atual os avanços feitos com relação aos efeitos da suplementação de cafeína sobre a força máxima e seus mecanismos associados a partir de 2010, ano em foram publicados dois importantes artigos. As buscas foram realizadas nas bases de dados PubMed, Medline, Scielo e Web of Science procurando-se artigos publicados após 2010. Dezesseis estudos foram incluídos com base nos critérios de inclusão e exclusão. Cinco estudos não relataram alterações da força voluntária máxima (31,3\%). Quatro deles usaram contrações musculares isométricas, embora isso possa não ser um fator chave, porque outros cinco estudos também usaram contrações isométricas e relataram efeitos ergogênicos. Além disso, esses quatro estudos avaliaram pequenos grupos musculares e os voluntários não eram habituados à cafeína. A cafeína produziu efeitos ergogênicos em 11 dos 16 estudos analisados (68,8\%). Nenhuma dose foi claramente relacionada com efeitos ergogênicos; contudo, há indícios da necessidade de uma dose de pelo menos $3 \mathrm{mg} / \mathrm{kg}$ de cafeína. A ergogenicidade da cafeín a foi afetada por vários fatores. Havia uma falta de protocolos padronizados e controle de fatores intervenientes (por exemplo, ciclo circadiano e estado nutricional) que poderiam afetar os resultados. Ainda é preciso definir um protocolo ideal de suplementação de cafeína que seja útil para futuras pesquisas, atletas e praticantes de atividade física. Um pequeno avanço feito desde 2010 envolveu a possivel falta de diferença de gênero - parece que a suplementação de cafeína afeta homens e mulheres igualmente. Nível de Evidência l; Revisão Sistemática de Estudos de Nível I.

Descritores: Substâncias para melhoria do desempenho; Citocromo P-450 CYP1A2; Antagonistas do receptor A2 de adenosina; Treinamento de resistência; Músculo quadríceps; Contração muscular.

\section{RESUMEN}

El objetivo de esta revisión fue examinar en la literatura actuallos avances hechos con respecto a los efectos del suplemento de cafeína sobre la fuerza máxima y sus mecanismos asociados desde 2010, año en que se publicaron dos artículos importantes. Las búsquedas se realizaron en las bases de datos PubMed, Medline, Scielo y Web of Science, por artículos publicados después de 2010. Se incluyeron 16 estudios basados en los criterios de inclusión y exclusión. Cinco estudios no reportaron cambios de la fuerza voluntaria máxima (31,3\%). Cuatro de ellos usaron contracciones musculares isométricas, aunque esto puede no ser un factor clave, porque otros cinco estudios también utilizaron contracciones isométricas y reportaron efectos ergogénicos. Además, estos cuatro estudios evaluaron grupos musculares pequeños y los voluntarios no tenían el hábito de consumo de cafeína. La cafeína produjo efectos ergogénicos en 11 de los 16 estudios analizados (68,8\%). Ninguna dosis fue claramente relacionada con efectos ergogénicos, sin embargo, hay indicios de la necesidad de una dosis de al menos $3 \mathrm{mg} / \mathrm{kg}$ de cafeína. La ergogenicidad de la cafeína se vio afectada por varios factores. Hubo una falta de protocolos y controles estandarizados de factores intervinientes (por ejemplo, 
ciclo circadiano y estado nutricional) que podrían afectar los resultados. Todavía es necesario definir un protocolo ideal de suplemento de cafeína que sea útil para futuras investigaciones, atletas y practicantes de actividad física. Un pequeño avance hecho desde 2010 involucró la posible falta de diferencia de género - parece que el suplemento de cafeína afecta a hombres y mujeres igualmente. Nivel de Evidencia l; Revisión sistemática de estudios de Nivel I.

Descriptores: Sustancias para mejorar el rendimiento; Citocromo P-450 CYP1A2; Antagonistas del receptor de adenosina A2; Entrenamiento de resistencia; Músculo cuádriceps; Contracción muscular.

\section{INTRODUCTION}

Caffeine (1,3,7-trimethylxanthine) is one of the most consumed psychoactive substances worldwide due to its presence in various foods and drinks, such as coffee, tea, and chocolate. For more than one hundred years, caffeine has been known to have an ergogenic effect on muscular work. 'In particular, the efficacy of caffeine has been well-documented in dynamic exercise in which aerobic metabolism predominates. ${ }^{2}$ A recent study showed that $74 \%$ of competitive athletes use caffeine due to its ergogenic capabilities. ${ }^{3}$

Caffeine is also present in a wide range of nutritional supplements known as "pre-workouts"that are consumed by physically active people who seek to increase their performance. ${ }^{4-6}$ Unlike in predominantly aerobic exercises in which the effects of caffeine are well-known, the effects of caffeine in strength training and on maximum strength remain controversial. ${ }^{2}$

Muscle strength plays an important role in health. Low levels of strength are associated with mortality, cancer and loss of functionality. ${ }^{7-9}$ Muscle strength is crucial in athletics and is a decisive factor for sports that involve maximum strength production, such as weight lifting and shot put. ${ }^{5}$

Studies in the 1980s have shown conflicting effects of caffeine, and their results ranged from no effects to small positive effects to significant effects on maximum strength. ${ }^{5}$ Several reviews have been compiled ${ }^{2,10}$ including a recent a systematic review ${ }^{11}$ and meta-analysis. ${ }^{12}$ This meta-analysis is singular regarding this subject, and it reported important findings, which indicated that the effect of caffeine supplementation is independent of training status and ingestion means. However, the analysis indicated that the effects of caffeine are highly dependent on the tested muscle group.

In the systematic review, Astorino and Roberson ${ }^{11}$ highlighted other unresolved issues, such as the relationship between caffeine habituation and ergogenic effects, and reinforced the importance of questionnaires to quantify individual caffeine consumption. The authors also hypothesized that the caffeine abstention protocol could create false positive effects if caffeine abstinence was symptomatic, i.e., a participant would present lower control and placebo strength values compared to their "normal" strength when caffeine is not restricted.

Therefore, the aim of this study was to systemically review recent data caffeine supplementation (CAFF) and its effect on maximum strength performance, particularly considering its advances since 2010, having previous research ${ }^{11,12}$ as a cornerstone. An additional goal was to analyze possible mechanisms associated with CAFF effects.

\section{METHODS}

The following key words were used: caffeine and (strength or force or torque) to search for papers that investigate the effect of CAFF on maximum strength. Maximum strength was defined as: 1) the largest value of force or torque produced during a muscle contraction and 2) the greatest load that could be lifted during a single isotonic contraction. The search was carried out in the PubMed, Medline, Scielo and Web of Science databases.
The authors chose to include only articles published after 2010, because in that same year were published two important review articles which extensively discussed all publications up to 2009.11,12 Thus, the search period was from January 2010 to September 2016, the most recent date possible considering the writing, reviewing and submission of the manuscript.

To be included, studies needed to meet the following inclusion criteria: 1) Study used healthy men, women, or both as participants i.e. the study should clearly state participants are healthy or that they do not possess any disease, condition or injury that may influence the main outcome 2) Present at least two experimental sessions, one with CAFF and another with placebo and 3) Measure maximum strength according to the definitions mentioned above. The exclusion criteria were: 1) The effect observed by the study could not be solely attributed to CAFF, 2) other ergogenic or potentially ergogenic compound was used along with CAFF, 3) CAFF was mouthrinsed or chewed but not ingested, 4) participants were fatigued before the supplementation, 5) usage of special groups (cancer survivors, diabetics, etc.) and 6) the study was not published in a peer reviewed journal (i.e. abstract of a meeting or conference). All exercise interventions and all study designs were eligible as long as they attended inclusion and exclusion criteria. A total of 642 articles were found, 602 of which did not meet the inclusion criteria, based on the observation of each abstract and title or were duplicates. A total of 40 articles were then fully examined and, according to the exclusion criteria, 24 more articles were removed, thus leaving 16 articles to be examined in this review. The process of article retrieval is outlined in Figure 1.

\section{RESULTS}

Table 1 summarizes the findings of the included studies.

\section{Methodological Aspects}

Almost all study participants were evaluated under both the experimental and placebo conditions (93.8\%). Fourteen studies included crossover placebo-controlled designs, with eleven double-blind studies (78.6\%) and only three single-blind studies (21.4\%). ${ }^{13-15}$ Only one study used a balanced placebo design, although single-blinded, ${ }^{16}$ but a very useful design to control expectancy effect. ${ }^{17,18}$ One study did not use a crossover design, but it was double-blind. ${ }^{19}$ Only four studies (25.0\%) reported the time of day when measurements were recorded, and eight (50.0\%) do not even mention whether the time of day was maintained for the duration of the experiments. Most studies also used parametric statistics. Surprisingly, only seven studies (43.8\%) reported using normality tests. ${ }^{15,16,20-24}$ However, the normality tests were on small samples ( $\mathrm{n}=10$ to 18 ), which produce an inherent bias because such samples tend to have nonparametric distributions. ${ }^{25}$ Only three studies (18.8\%) performed analyses of the blinding procedures. ${ }^{13,15,16}$ In two cases, $50 \%$ of volunteers indicated which day they received CAFF. The study using a balanced placebo design seemed to adequately deceive all the volunteers. 


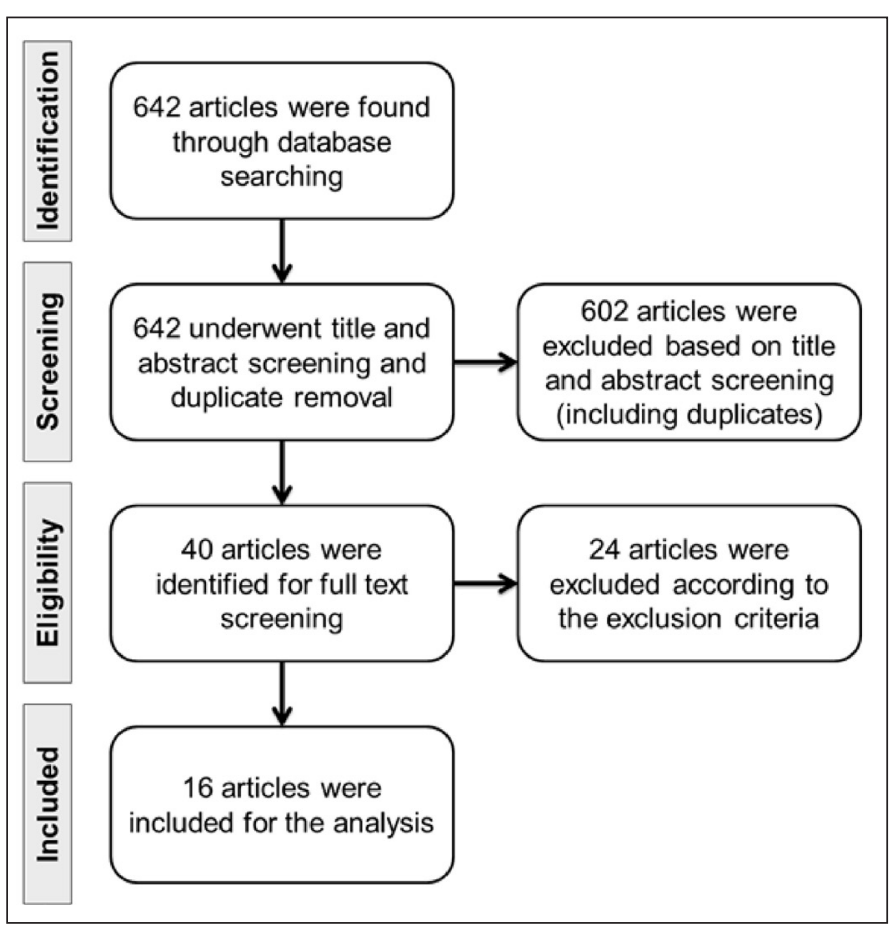

Figure 1. Flow diagram for article selection process.

Interestingly, only one study included untrained volunteers. Two studies (12.5\%) included highly trained volunteers, whereas the other 13 studies (81.3\%) examined active or highly active volunteers. Eight studies (50.0\%) did not report on the strength training experience of their participants. CAFF was administered orally via capsules, taken with water (56.3\%) or as dissolved powder in water one hour before exercise $(87.5 \%$ ) in a wide range of doses (2 to $10 \mathrm{mg} / \mathrm{kg}$ ). Only one study used coffee as a source of CAFF, and it was the only one that used an absolute dose.

\section{Caffeine effect on strength}

Four studies (25.0\%) did not observe increased maximum strength for any condition. One study observed strength increase only in electrically evoked contractions. Therefore, a total of five studies (31.3\%) did not observe increased voluntary maximum strength and four of them used isometric contractions (as indicated at the end of Table 1). The type of contraction does not seem to be a key factor because five other studies using isometric contractions reported ergogenic effects. ${ }^{21,22,26-28}$ The five studies that did not observe increased strength included volunteers not habituated to caffeine or with low caffeine consumption and four of them 20,24,29,30 evaluated the strength of smaller muscle groups. Hence, the ergogenic effects of CAFF were present in voluntary muscle contraction in eleven (68.8\%) of the 16 analyzed studies.

\section{Muscle group interaction}

One of the most studied muscle groups was the knee extensors, which was examined in eight (50.0\%) of the 16 analyzed studies. Ergogenic effects were observed in six (75.0\%) of the eight studies. Smaller muscle groups, such as the plantar flexors, were examined in three studies, but ergogenic effects were only observed in one of the three studies (33.3\%).

\section{DISCUSSION}

Based on the selected studies (Table 1), CAFF frequently produced ergogenic effects on the strength of healthy men and women. Although frequent, the magnitude of increase may not be clinically meaningful e.g., Goldstein et al. ${ }^{31}$ reported a mean significant increase of $0.8 \mathrm{~kg}$ $(1,5 \%)$ in a one repetition maximum test (1RM).

\section{Muscle group interaction}

A possible explanation for a greater effect of CAFF on knee extensors when compared to other muscles is due to the mechanism of action of caffeine. Increased muscle activation results in higher motor unit recruitment to perform mechanical work. ${ }^{12}$ Knee extensors have a lower muscle activation requirement during dynamic contractions with respect to its maximal activation. The smaller muscle groups have activation levels closer to their maximum during dynamic contractions. Therefore, bigger muscle groups have a larger capacity for increased strength. ${ }^{12}$

To verify the relationship between muscle group size and the effect of CAFF, Timmins and Saunders ${ }^{15}$ compared four distinct muscle groups, i.e., knee extensors, plantar flexors, elbow flexors and wrist flexors. CAFF increased peak torque (tested at $60^{\circ} / \mathrm{s}$ ) in all muscles groups. The authors reported that CAFF had a trend to affect the bigger muscle groups to a greater degree $(p=0.056)$, with bigger muscles exhibiting larger effect sizes $-0.53,0.43,0.38,0.36$, respectively. Instead, when observing through the classification of these effect sizes the actually may indicate that CAFF has a greater effect in the knee extensors than in other muscles - agreeing with the findings of Warren et al. ${ }^{12}$ - rather than a true CAFF relationship with muscle size.

\section{Muscle Contraction Type}

As shown in Table 1, the last five studies did not observe increases in voluntary maximum strength. Four of these studies investigated isometric contractions. Similarly, Black et al. ${ }^{27}$ did not observe any increases in strength when testing isometric contractions of elbow flexor muscles. Warren et al. ${ }^{12}$ did not observe any differences when comparing isokinetic and isometric contractions in their meta-analysis; however the findings above mentioned indicate that this issue should be further investigated.

Recently, Behrens et al. ${ }^{21}$ observed that CAFF exerted significant effects on the three types of contraction, i.e., concentric, isometric and eccentric. However, the reported results were limited because the authors used electric stimulation during voluntary contractions. Bazzucchi et al. ${ }^{26}$ reported increases in isometric strength, these results showed significant differences between the placebo and CAFF conditions but not between the CAFF and the pre-supplementation conditions. Nine studies were conducted using isometric contractions, five (55.6\%) did not observe ergogenic effects on at least one of the muscle groups examined. This may be because the level of knee extensor muscle activation during isometric contractions is closer to the maximum value compared to during concentric muscle contraction. ${ }^{32}$ In these conditions, it would be easier to increase the strength of concentric contractions due to the larger capacity for an increase in activation. ${ }^{12}$ Thus, there is a need for more studies to directly compare if CAFF exerts differential effects in different types of muscle voluntary contractions, since the results of Behrens et al..$^{21}$ not necessarily can be extrapolated because of the use of electrical stimulation.

\section{Mechanisms involved in strength increase}

Increased muscle activation seems to be related to the ergogenic effects of CAFF. ${ }^{12}$ For example, Black et al. ${ }^{27}$ observed increased activation after CAFF in knee extensors but not in elbow flexors. This observation correlated with an increase in strength, which only increased in the knee extensors. Studies that observed increased muscle activation also observed increases in strength, ${ }^{21,23,26}$ whereas other studies that did not observe increased activation did not observe increases in strength. 20,30

Regarding training experience, only one study used untrained participants, ${ }^{16}$ with positive CAFF effects being reported. Warren et al. ${ }^{12}$ were unable to correlate training experience with the effects of CAFF. However, the notion that untrained participants are unable to respond to CAFF seems to prevail as mentioned by Goldstein et al. ${ }^{10}{ }^{10}$ most studies 
Table 1. Characteristics of the analysed studies.

\begin{tabular}{|c|c|c|c|c|c|c|c|c|c|c|}
\hline Study & Participants & $\begin{array}{l}\text { Study } \\
\text { Design }\end{array}$ & $\begin{array}{l}\text { Caffeine } \\
\text { dosage }\end{array}$ & $\begin{array}{l}\text { Caffeine } \\
\text { restriction } \\
\text { protocol }\end{array}$ & $\begin{array}{c}\text { Caffeine } \\
\text { consumption }\end{array}$ & \begin{tabular}{|c|} 
Nutritional \\
state (at \\
supplementation \\
moment)
\end{tabular} & $\begin{array}{c}\text { Contraction } \\
\text { type }\end{array}$ & $\begin{array}{l}\text { Muscular } \\
\text { action or } \\
\text { exercise }\end{array}$ & $\begin{array}{l}\text { Strength } \\
\text { measure }\end{array}$ & Findings \\
\hline $\begin{array}{l}\text { Diaz-Lara } \\
\text { et al., (2016) }\end{array}$ & $14 \mathrm{M}$ & $\mathrm{DB}, \mathrm{CO}, \mathrm{PL}$ & $3 \mathrm{mg} / \mathrm{kg}$ & $\begin{array}{c}48 \mathrm{~h} \text { restriction } \\
\text { before tests }\end{array}$ & $<60 \mathrm{mg} /$ day & $\begin{array}{l}\text { SM ( } 3 \text { h before } \\
\text { the test) }\end{array}$ & ISO, CON & $\mathrm{HG}, \mathrm{BP}, \mathrm{VJ}$ & $\begin{array}{l}\text { MVC, 1RM, } \\
\text { PFVJ }\end{array}$ & $\begin{array}{c}\uparrow \mathrm{MVC}(\mathrm{HG}), \\
1 \mathrm{RM}(\mathrm{BP}) \\
\leftrightarrow \mathrm{PFVJ} \\
\end{array}$ \\
\hline $\begin{array}{l}\text { Tallis et al., } \\
\text { (2016) }\end{array}$ & $11 \mathrm{M}$ & $\mathrm{BPD}$ & $5 \mathrm{mg} / \mathrm{kg}$ & $\begin{array}{c}48 \mathrm{~h} \text { restriction } \\
\text { before tests }\end{array}$ & $91.8 \pm 16.1 \mathrm{mg} /$ day & Not reported & CON & $K E, K F$ & $\begin{array}{c}\text { PT, MT } \\
\left(30,120^{\circ} / \mathrm{s}\right)\end{array}$ & $\begin{array}{l}\text { KE: } \uparrow \text { PT, MT } \\
\text { (both speeds) } \\
\text { KF: } \leftrightarrow \text { PT, MT } \\
\text { (both speeds) } \\
\end{array}$ \\
\hline $\begin{array}{l}\text { Bloms } \\
\text { et al., (2016) }\end{array}$ & $\begin{array}{l}16 \mathrm{M} \\
9 \mathrm{~F}\end{array}$ & $\mathrm{SB}, \mathrm{CO}, \mathrm{PL}$ & $5 \mathrm{mg} / \mathrm{kg}$ & $\begin{array}{l}\text { No consumption } \\
\text { on the test day }\end{array}$ & $\begin{array}{c}64 \% \\
\text { nonconsumers. } \\
36 \% \text { consumed } \\
\text { regularly }\end{array}$ & $\begin{array}{l}3 \text { hour fast } \\
\text { before the test }\end{array}$ & CON & $\begin{array}{l}\text { CMJ } \\
\text { SJ }\end{array}$ & PFVJ & $\uparrow P F V J$ \\
\hline $\begin{array}{c}\text { Chen et al., } \\
\text { (2015) }\end{array}$ & $\begin{array}{l}10 \mathrm{M} \\
10 \mathrm{~F}\end{array}$ & $\mathrm{DB}, \mathrm{CO}, \mathrm{PL}$ & $6 \mathrm{mg} / \mathrm{kg}$ & $\begin{array}{c}7 \text { day restriction } \\
\text { (experimental } \\
\text { period) }\end{array}$ & $<200$ mg/week & $\begin{array}{c}8 \text { hour fast. SM } \\
\text { (together with } \\
\text { caffeine) }\end{array}$ & ISO & KE & MVC & $\uparrow \operatorname{MVC}(\mathrm{M}, \mathrm{F})$ \\
\hline $\begin{array}{c}\text { Black et al., } \\
(2015)\end{array}$ & $\begin{array}{l}6 \mathrm{M} \\
9 \mathrm{~F} \\
\end{array}$ & $\mathrm{DB}, \mathrm{CO}, \mathrm{PL}$ & $5 \mathrm{mg} / \mathrm{kg}$ & $\begin{array}{c}\text { Minimum } 12 \\
\mathrm{~h} \text { restriction } \\
\text { before tests }\end{array}$ & $<40$ mg/day & $\begin{array}{l}\text { SM ( } 2 \text { h before } \\
\text { the test })\end{array}$ & ISO & $K E, E F$ & MVC, EET & $\begin{array}{c}\text { KE: } \uparrow \text { MVC, } \\
\leftrightarrow \text { EET; EF: } \leftrightarrow \\
\text { MVC e EET } \\
\end{array}$ \\
\hline $\begin{array}{c}\text { Behrens } \\
\text { et al., (2015)a }\end{array}$ & $\begin{array}{l}11 \mathrm{M} \\
3 \mathrm{~F}\end{array}$ & $\mathrm{DB}, \mathrm{CO}, \mathrm{PL}$ & $8 \mathrm{mg} / \mathrm{kg}$ & $\begin{array}{c}72 \mathrm{~h} \text { restriction } \\
\text { before tests }\end{array}$ & $\begin{array}{l}240 \pm 172 \\
\mathrm{mg} / \text { week }\end{array}$ & Not reported & $\begin{array}{c}\text { ISO, CON, } \\
\text { ECC }\end{array}$ & KE & $\begin{array}{c}\text { EET and MVC, } \\
\text { PT }\left(25^{\circ} / \mathrm{s}\right) \\
\end{array}$ & $\begin{array}{c}\uparrow \mathrm{PT} \text { and MVC } \\
\leftrightarrow \mathrm{EET} \\
\end{array}$ \\
\hline $\begin{array}{c}\text { Timmins e } \\
\text { Saunders } \\
(2014)\end{array}$ & $16 \mathrm{M}$ & $\mathrm{SB}, \mathrm{CO}, \mathrm{PL}$ & $6 \mathrm{mg} / \mathrm{kg}$ & $\begin{array}{l}24 \mathrm{~h} \text { restriction } \\
\text { before tests }\end{array}$ & $95.4 \pm 80$ mg/day & Not reported & CON & $K E, E F, W F, P F$ & PT $60^{\circ} / \mathrm{s}$ & $\begin{array}{c}\uparrow P T \\
(K E, E F, W F, P F)\end{array}$ \\
\hline $\begin{array}{l}\text { Duncan } \\
\text { et al., (2014) }\end{array}$ & $10 \mathrm{M}$ & $\mathrm{DB}, \mathrm{CO}, \mathrm{PL}$ & $6 \mathrm{mg} / \mathrm{kg}$ & $\begin{array}{c}\text { No consumption } \\
\text { after } 18 \text { PM } \\
\text { at the night } \\
\text { before testing }\end{array}$ & $\leq 70 \mathrm{mg} /$ day & Not reported & CON & KE & $\begin{array}{c}\text { PT }(30,150, \\
\left.300^{\circ} / \mathrm{s}\right)\end{array}$ & $\begin{array}{c}\uparrow \mathrm{PT} \\
\text { (all speeds) }\end{array}$ \\
\hline $\begin{array}{l}\text { Bazzucchi } \\
\text { et al., (2011) }\end{array}$ & $14 \mathrm{M}$ & $\mathrm{DB}, \mathrm{CO}, \mathrm{PL}$ & $6 \mathrm{mg} / \mathrm{kg}$ & $\begin{array}{c}4 \text { day restriction } \\
\text { before tests }\end{array}$ & $<200 \mathrm{mg} /$ week & Not reported & $\mathrm{ISO}, \mathrm{CON}$ & $\mathrm{EF}$ & $\begin{array}{c}\text { EET, MVC, PT } \\
(30,60,120 \\
\left.180,250^{\circ} / \mathrm{s}\right) \\
\end{array}$ & $\begin{array}{c}\uparrow \mathrm{PT} \\
\text { (all speeds); } \\
\uparrow \text { EET }\end{array}$ \\
\hline $\begin{array}{l}\text { Astorino } \\
\text { et al., (2010) }\end{array}$ & $15 \mathrm{M}$ & $\mathrm{SB}, \mathrm{CO}, \mathrm{PL}$ & $\begin{array}{l}5 \mathrm{mg} / \mathrm{kg} \\
2 \mathrm{mg} / \mathrm{kg}\end{array}$ & $\begin{array}{c}48 \mathrm{~h} \text { restriction } \\
\text { before tests }\end{array}$ & $\begin{array}{c}243.3 \pm 136.3 \\
\text { mg/day }\end{array}$ & Not reported & CON & $\mathrm{KE}, \mathrm{KF}$ & PT $\left(180^{\circ} / \mathrm{s}\right)$ & $\begin{array}{c}\leftrightarrow \text { PT KE } \\
(2,5 \mathrm{mg} / \mathrm{kg}) \\
\leftrightarrow \text { PT KF } \\
(2 \mathrm{mg} / \mathrm{kg}) \\
\uparrow \mathrm{PT} \mathrm{KF} \\
(5 \mathrm{mg} / \mathrm{kg}) \\
\end{array}$ \\
\hline $\begin{array}{c}\text { Goldstein } \\
\text { et al., (2010) }\end{array}$ & $15 \mathrm{~F}$ & $\mathrm{DB}, \mathrm{CO}, \mathrm{PL}$ & $6 \mathrm{mg} / \mathrm{kg}$ & $\begin{array}{c}24 \text { h restriction } \\
\text { before tests }\end{array}$ & 0-416 mg/day & 12 hour fast & $\mathrm{CON}$ & $\mathrm{BP}$ & $1 \mathrm{RM}$ & $\uparrow 1 \mathrm{RM}$ \\
\hline $\begin{array}{c}\text { Trexler } \\
\text { et al., (2016) } \\
\end{array}$ & $18 \mathrm{M}$ & $\mathrm{DB}, \mathrm{PL}$ & $\begin{array}{c}300 \mathrm{mg}(3-5 \\
\mathrm{mg} / \mathrm{kg})\end{array}$ & $\begin{array}{c}48 \text { h restriction } \\
\text { before tests }\end{array}$ & $32.9 \pm 59.6 \mathrm{mg} /$ day & Not reported & CON & $B P, L P$ & $1 \mathrm{RM}$ & $\leftrightarrow 1 \mathrm{RM}$ \\
\hline $\begin{array}{c}\text { Trevino } \\
\text { et al. (2015) } \\
\end{array}$ & $13 M$ & $\mathrm{DB}, \mathrm{CO}, \mathrm{PL}$ & $\begin{array}{c}5 \mathrm{mg} / \mathrm{kg} \\
10 \mathrm{mg} / \mathrm{kg}\end{array}$ & $\begin{array}{l}\text { No consumption } \\
\text { on the test day }\end{array}$ & \begin{tabular}{|l|}
$92.3 \%$ reported to \\
be caffeine naive \\
\end{tabular} & Not reported & ISO & $\mathrm{EF}$ & MVC & $\leftrightarrow \mathrm{MVC}$ \\
\hline $\begin{array}{c}\text { Behrens } \\
\text { et } a l_{.},(2015) b \\
\end{array}$ & $\begin{array}{l}7 \mathrm{M} \\
6 \mathrm{~F} \\
\end{array}$ & $\mathrm{DB}, \mathrm{CO}, \mathrm{PL}$ & $7 \mathrm{mg} / \mathrm{kg}$ & $\begin{array}{c}72 \mathrm{~h} \text { restriction } \\
\text { before tests }\end{array}$ & $\begin{array}{l}170 \pm 156 \\
\mathrm{mg} / \text { week }\end{array}$ & Not reported & ISO & PF & MVC, EET & $\leftrightarrow \mathrm{MVC}, \mathrm{EET}$ \\
\hline $\begin{array}{c}\text { Mora-Rodrigues } \\
\text { et al., (2012) }\end{array}$ & $12 \mathrm{M}$ & $\mathrm{DB}, \mathrm{CO}, \mathrm{PL}$ & $3 \mathrm{mg} / \mathrm{kg}$ & $\begin{array}{c}4 \text { day restriction } \\
\text { before tests }\end{array}$ & $\leq 60 \mathrm{mg} /$ day & $\begin{array}{l}\text { SM (together } \\
\text { with caffeine) }\end{array}$ & ISO & $\mathrm{KE}, \mathrm{HG}$ & MVC, EET & $\begin{array}{c}\leftrightarrow \leftrightarrow \mathrm{MVC} \\
(\mathrm{KE}, \mathrm{HG}) \\
\uparrow \mathrm{EET} \mathrm{KE} \\
\text { (morning test) } \\
\end{array}$ \\
\hline $\begin{array}{c}\text { Fimland } \\
\text { et al., (2010) }\end{array}$ & $13 \mathrm{M}$ & $\mathrm{DB}, \mathrm{CO}, \mathrm{PL}$ & $6 \mathrm{mg} / \mathrm{kg}$ & $\begin{array}{c}36 \text { h restriction } \\
\text { before tests }\end{array}$ & $145 \pm 88 \mathrm{mg} /$ week & Not reported & ISO & PF & MVC & $\leftrightarrow \mathrm{MVC}$ \\
\hline
\end{tabular}

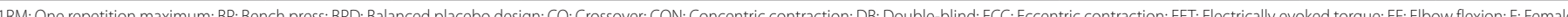

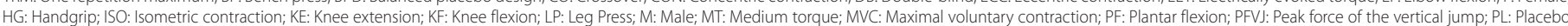
HG: Handgrip; ISO: Isometric contraction; KE: Knee extension; KF: Knee flexion; LP: Leg Press; M: Male; M
controlled; PT: Peak torque; SB: Single-blind; SM: Standardized Meal; VJ:Vertical Jump; WF:Wrist flexion.

in our review did not evaluate untrained participants. Physiological differences between trained and untrained individuals could cause a differential response to CAFF. The neuromuscular adaptations to training are known, such as changes in antagonist muscle co-activation, increases in motor neuron firing rates and increases in motor unit recruitment. ${ }^{33}$ Because untrained individuals have a lower recruitment capacity of motor units, it would be logical to assume that these untrained individuals would likely present a greater response to CAFF due to the larger capacity for increased muscle activation. Factors affecting CAFF and its mechanisms require further investigation. Still considering the Mizuno et al. ${ }^{34}$ observed a greater adenosine $A_{2 A}$ receptor density in muscle of endurance-trained men; we do not know any study that investigated the relationship between adenosine $A_{2 A}$ receptor density, CAFF ergogenic effect and training experience.

In addition to the mechanisms related to adenosine antagonism, CAFF also seems to elicit peripheral effects. Mohr et al..$^{35}$ observed positive effects of CAFF in tetraplegic men during exercise under electrical stimulation. The ergogenic effects of CAFF may be attributed to central (e.g., CNS) and peripheral factors. ${ }^{36}$

Five studies in this review assessed whether CAFF increased strength in electrically evoked muscle contractions. Two studies observed increased strength and three studies did not observe increased strength. There were no obvious differences between the studies to account for these conflicting results. Other studies ${ }^{36,37}$ have shown that a possible mechanism responsible for the effects of CAFF is increased calcium release from the sarcoplasmic reticulum. However, the required caffeine dose at which this effect is observed is usually supraphysiological. ${ }^{11,38}$ However, Tallis et al. ${ }^{39}$ noted that CAFF exerted an ergogenic effect in muscle contractions at physiological doses. Interestingly, there was a larger effect in force production in slow muscle fibers than in fast muscle fibers. The authors attributed this to the specific calcium dynamics in the different muscle fibers. In humans, an explanation for a possible interaction between CAFF and peripheral sites is warranted. 
None of the analyzed studies investigated the plasma levels of CAFF, therefore no relationship between its pharmacokinetics and effect could be established. It may also be important to investigate the plasma levels of CAFF metabolites, since they may also have ergogenic properties ${ }^{40,41}$ and their relationship to CAFF ergogenicity is unknown.

The findings of the studies included in this review were attributed to central and peripheral mechanisms. Interestingly, eight studies (50.0\%) mentioned the peripheral mechanisms, citing the following: 1) a higher calcium release, ${ }^{14,19,22-24,26,28,30}$ 2) a greater sodium/potassium ATPase pump activity, 19,22,28 3) an increased muscle sensitivity to calcium, ${ }^{26,28} 4$ ) inhibition of phosphodiesterase, 22 ) a lower reabsorption of calcium from the sarcoplasmic reticulum, 6) a higher muscle fiber conduction velocity, and 7) a greater excitability of muscle sarcolemma. ${ }^{26}$ Two studies mentioned that individual CAFF metabolism capacity could explain the occurrence of responders and nonresponders in their results. ${ }^{13,14}$ In contrast, all studies cited the ergogenic mechanisms of CAFF as antagonists to adenosine and focused on the central effects, e.g., increased motor unit recruitment, increased muscle activation, increased CNS activity, increased neural drive to the muscles increased neurotransmitter release in the CNS, decreased perception of pain, increased CNS dopamine transmission, increased motoneuronal excitability, decreased perception of exertion, increased sympathetic activity, increased CNS serotonin transmission, and better intra and inter-muscular coordination during muscle contractions. Based on the findings of the present review, agreeing with a previous meta-analysis, ${ }^{12}$ there is an important association between increasing muscle activation and CAFF ergogenic effect.

\section{Methodological aspects that may influence caffeine research results}

Men and women may respond differently to CAFF, especially considering that caffeine metabolism and clearance are affected by menstrual cycle and by the use contraceptive drugs. ${ }^{38}$ Most studies evaluated men; two studies investigated CAFF effect on muscle strength in women (12.5\%), and four studies (25.0\%) included men and women in their sample groups. Only one of the four studies did not observe positive effects of CAFF. Three papers addressed the possible gender effect on CAFF, 20,21,28 but only one controlled for intervening factors - tests occurred during early follicular phase with volunteers that did not use contraceptives. ${ }^{28}$ Bloms et al. ${ }^{14}$ reported that the percentage of CAFF responders in women seemed similar to men - no statistical analysis was performed. Chen et al..$^{28}$ directly compared the effect of CAFF on men and women, with both responding equally. This could indicate a lack of difference in the effect of CAFF between men and women, although much more research on the subject is needed. These findings are an advance, considering that previous reviews and meta-analysis ${ }^{2,11,12}$ could not compare the response of men and women to CAFF due to the lack of the studies using only females and comparing men and women.

Another important point to address is the relationship between CAFF and habituation to caffeine. In endurance exercises, CAFF produced smaller effects in caffeine-habituated participants than in nonhabituated participants. ${ }^{42}$ However, regarding maximal strength, this difference may not occur. There is little evidence that CAFF could have an equal effect, ${ }^{36}$ or a larger effect on habituated participants. ${ }^{11,14,43}$ This conclusion correlates well with the findings of this review. Four studies using nonhabituated participants or low CAFF consumers observed no ergogenic effects. Astorino and Roberson ${ }^{11}$ explored two potential explanations for these observations. First, the ergogenic effects observed in CAFF studies were related to the reversal of withdrawal symptoms caused by the CAFF restriction protocol; as shown in Table 1, these CAFF restriction protocols are quite diverse. Second, caffeine consumers were more sensitive to the positive effects of CAFF; therefore, CAFF promoted larger effects. For example, Cornelis et al. ${ }^{44}$ noted that a higher consumption of CAFF was associated with a lowered chance of having genes related to excessive anxiety responses to CAFF. This draws attention to the need for further investigation on this subject.

Another conflicting variable is the nutritional state of the participant at the moment of CAFF. According to Skinner et al., ${ }^{45}$ the concomitant consumption of carbohydrates and CAFF affected the bioavailability of caffeine. Thus, it may be possible that the nutritional state affects CAFF response and may influence the result of the studies presented. Notably, $62.5 \%$ of the studies did not report nutritional states - showing the need for researchers to better control intervening variables.

Another important variable is the time of the day at which the tests were carried out. Only four studies (25.0\%) reported the time at which tests occurred, and three of these studies observed increases in strength due to CAFF. Mora-Rodrigues et al. ${ }^{46}$ considered that the ergogenic effects of CAFF would be dependent on circadian rhythms. Because muscle strength is typically greater in the afternoon, the authors proposed that CAFF benefits would only be observed in the morning, i.e., the increased strength due to morning CAFF would be comparable with the measured strength in the afternoon. However, the conclusions of this study were based in bar displacement velocity measurements and not directly on measured strength. Thus, these findings may not be applied to maximal voluntary strength. In another work by Mora-Rodriguez et al.,. ${ }^{24}$ the bar displacement velocity increased, but the maximal voluntary strength did not increase. This issue remains unresolved.

Regarding the CAFF dosage, no associations were observed with the effectiveness of CAFF due to the varying results. Black et al. ${ }^{27}$ used 5 $\mathrm{mg} / \mathrm{kg}$ of CAFF and observed positive effects. Trevino et al. ${ }^{30}$ used 5 and $10 \mathrm{mg} / \mathrm{kg}$ of CAFF and observed no increases in strength. While the use of different muscle groups may further complicate these comparisons, a dose and effect relationship may still exist. Astorino et al. ${ }^{13}$ compared two different doses ( 2 and $5 \mathrm{mg} / \mathrm{kg}$ ) of CAFF; only the highest dose was observed to exert an effect on the knee flexor muscles. Pallares et al. ${ }^{47}$ observed a clear dose-response relationship when analyzing bar displacement velocities. Consequently, regarding maximum strength, there probably is a minimum CAFF dose that increases strength; however, we do not know yet which dose it is and whether a dose-response relationship indeed exists. Caution is necessary when dealing with high doses, as side effects seem to increase concurrently. ${ }^{47}$

Ergogenic effects are expected to be observed one hour after supplementation when peak serum caffeine levels are also expected. ${ }^{11}$ In this review, $87.5 \%$ of the studies measured the ergogenic effects one hour after supplementation. Only two studies assessed the effects of CAFF 30 minutes after supplementation, 15,19 and positive effects were reported in only one study. In endurance exercises, Skinner et al. ${ }^{48}$ observed greater CAFF effects one hour after supplementation than when the moment peak serum CAFF levels occurred. These finding indicate that the protocols used to measure CAFF effects should be further explored, particularly regarding the onset of CAFF ergogenicity. This a considerable importance, if you have the same results when using CAFF 30 or 60 minutes before exercise, you decrease the time spent in the lab, and maybe easier for an athlete to use CAFF before a competition.

An important variable not always considered is the caffeine metabolism capacity of each individual. Even though the metabolism of caffeine is known to occur in the liver by the P4501A2 cytochrome, the breakdown rate widely varies between individuals. ${ }^{11}$ The consequences of such variability on the findings of the studies in this review are unknown. Epidemiologic studies have shown the importance of this factor. When regularly consuming coffee, individuals with slow caffeine metabolism capacities have higher risks of developing hypertension and 
experiencing a first, nonfatal heart attack, whereas individuals with fast caffeine metabolism capacities have lower risks of developing hypertension and myocardial infarction episodes. ${ }^{49,50}$ Meyers and Cafarelli51 reported large variabilities in responses to CAFF when analyzing timeto-exhaustion at submaximal isometric contractions. These differences could be attributed to individual CAFF metabolism capacities, which are determined by the P4501A2 cytochrome. The investigation of the theme is still scarce, a few articles involving endurance exercise have been published; however, with conflicting results, 52,53 which makes it an open field of investigation for CAFF research.

Kalmar ${ }^{38}$ commented on the variations in responses to CAFF and suggested that studies should use larger samples to ensure sufficient statistical power in the analyses of CAFF effects, especially on strength; however, most of CAFF research still use a small number of volunteers. Considering the possibility of responders and nonresponders to CAFF, it is clear that is important every research to strive to increase the number of volunteers that participate.

It is not known whether CAFF expectancy can somehow affect the results of the investigations. Recent work has shown that the expectation of CAFF can result in "ergogenic" effects - placebo effect. ${ }^{54}$ Such effects occur in endurance exercise ${ }^{55,56}$ and strength based exercise..$^{57,58}$ One study, ${ }_{1}^{16}$ addressed this issue by using a balanced placebo design to control the influence of CAFF expectation. Their research showed that CAFF increased strength of the knee extensors independent of the expectation; however, knee flexors strength did not increase at all.

The lack of standardized protocols and the lack of control for the intervening factors, such as circadian cycles and nutritional states, could possibly interfere with the results of researches. This review recommends further studies controlling for intervening factors that could potentially affect the ergogenic effects of CAFF. In light of the discussed works, Figure 2 shows recommendations and directions for new research in this field by highlighting points that require further investigation.

\section{Limitations}

One possible limitation to this review was that the literature search was restricted to only four databases, which could give rise to publication bias. However, these databases include a large collection of articles from a number of reputable journals. Thus, we believe that the use of these databases do not undermine the present review. Furthermore, when considered the findings of Warren et al. ${ }^{12}{ }^{12}$ no biases are attributable when comparing the results of published and unpublished studies. Another limitation of this review is that the whole literature about CAFF was not analyzed; however, this does not undermine the present work since there already exist several high quality reviews published about the subject review work published until 2010,2,5,12,13 thus, the authors believed that it was necessary to analyze what has been done since 2010 and what still needs research.

\section{Perspectives}

According to Warren et al. ${ }^{12}$ CAFF exerts a modest effect on maximum strength of approximately 4\%; this may have an important practical influence for athletes. An excellent example is the London Olympics results in the 94.01 - $105.00 \mathrm{~kg}$ bodyweight category, the difference between the first, second and third place was quite small - 412,411, $410 \mathrm{~kg}$ - a 0,49\% of variation between third and first place. In the same category, if the sixth place had his performance increased $4 \%$ he would have been the Olympic champion. ${ }^{59} \mathrm{~A}$ limitation to this analysis is that CAFF research has used recreationally active men predominantly rather than athletes i.e. the effect on athletes may be different as the interaction between training status and CAFF is still unknown on strength. Thus,
Recommendations for researchers:

Work with larger samples due to the great variation of responses (approximately 30).

Control and report the time of day in which the tests were performed.

Report the nutritional state of the volunteers.

Report the percentage of responders and nonresponders.

\section{Suggestions and directions for new research:}

Compare the effect of caffeine supplementation in caffeine habituated and nonhabituated subjects.

Compare the effect of caffeine supplementation in subjects with different muscle fiber type predominance (ex: marathon runners vs weightlifters)

Investigate if the fiber type predominance in a certain muscle affects caffeine response.

Investigate the relation between circadian cycle variation and caffeine ergogenicity.

Investigate how long it takes to experience the ergogenic effect of caffeine.

Investigate the effects of different caffeine restriction protocols on caffeine ergogenicity, especially in caffeine habituated subjects.

Investigate if the nutritional state affects caffeine supplementation ergogenicity and its onset.

Investigate if the effect of caffeine supplementation has a dose-response relationship.

Investigate if the density of the adenosine receptors in the skeletal muscle studied affects caffeine ergogenicity.

Investigate if there is a relationship between caffeine side-effects reported and being a caffeine responsive individual.

Investigate the degree of association between muscle activation increase and muscular strength; i.e. how much it contributes to caffeine ergogenicity.

Investigate if the individual caffeine metabolism capacity (cytochrome P4501A2 activity) affects the caffeine ergogenicity.

Investigate if there is a genetic predisposition to respond to caffeine using the ADORA2A and/or the CYP1A2 polymorphisms.

Figure 2. Recommendations and suggestions for new studies based on the findings of this review.

we reiterate the importance of a better understanding of mechanisms and protocols involving CAFF, in order to potentiate its ergogenicity.

An ideal CAFF supplementation protocol that is useful for both future research and for athletes and physical activity practitioners has yet to be defined. More than 100 years have passed, and we still do not know how to get the most out of CAFF, and remarkably, we still lack research with those groups who could benefit the most of its small beneficial effect, e.g., there seems to be an absence of peer-reviewed published studies regarding CAFF and Olympic weightlifting and other competitive sports that involve elite strength performance.

\section{CONCLUSION}

Caffeine research is over a century old, but many questions still remained unanswered. A meta-analysis and systematic review published in 2010 could have been a cornerstone for new research in this area; however, most of the research published since then has not aimed at filling the gaps of the area; most keep doing more of the same. This study highlights a small step forward regarding a possible lack of gender difference; CAFF seems to affect men and women equally. Our study adds pointing out gaps that still need to be filled, especially regarding methodological aspects and intervening factor that may influence research. Currently, there still is no optimal protocol to ensure that CAFF will increase strength, which makes it difficult to study and prescribe CAFF.

All authors declare no potential conflict of interest related to this article 
AUTHORS' CONTRIBUTIONS: Each author made significant individual contributions to this manuscript. ES (0000-0002-3696-9556)* contributed substantially to the design, acquisition of data, literature search, analysis and interpretation of data, discussion of results, drafting and review of the final version of the manuscript. GG (0000-0002-2340-4054)* contributed to the design, acquisition of data, review of the manuscript and discussion of results. GM (0000-0002-5937-079X)* and KF(0000-0003-4262-0403)* contributed to the design, discussion of results, critical review of intellectual content, writing, review and final approval of the manuscript version. All authors revised the manuscript and approved the final version of the article. ${ }^{*} \mathrm{ORCID}$ (Open Researcher and Contributor ID).

\section{REFERENCES}

1. Rivers WH, Webber HN. The action of caffeine on the capacity for muscular work. J Physiol. 1907;36(1):33-47.

2. Sökmen B, Armstrong LE, Kraemer WJ, Casa DJ, Dias JC, Judelson DA, et al. Caffeine use in sports: considerations for the athlete. J Strength Cond Res. 2008;22(3):978-86.

3. Del Coso J, Muñoz G, Muñoz-Guerra J. Prevalence of caffeine use in elite athletes following its removal from the World Anti-Doping Agency list of banned substances. Appl Physiol Nutr Metab. 2011;36(4):555-61.

4. Alves C, Lima RVB. Dietary supplement use by adolescents. J Pediatr (Rio J.). 2009;85(4):287-94.

5. Burke LM. Caffeine and sports performance. Appl Physiol Nutr Metab. 2008;33(6):1319-34.

6. Eudy AE, Gordon LL, Hockaday BC, Lee DA, Lee V, Luu D, et al. Efficacy and safety of ingredients found in preworkout supplements. Am J Health Syst Pharm. 2013;70(7):577-88.

7. Brill PA, Macera CA, Davis DR, Blair SN, Gordon N. Muscular strength and physical function. Med Sci Sports Exerc. 2000;32(2):412-6.

8. Ruiz JR, Sui X, Lobelo F, Lee D-C, Morrow JR, Jackson AW, et al. Muscular strength and adiposity as predictors of adulthood cancer mortality in men. Cancer Epidemiol Biomarkers Prev. 2009;18(5):1468-76.

9. Ruiz JR, Sui X, Lobelo F, Morrow JR, Jackson AW, Sjöström M, et al. Association between muscular strength and mortality in men: prospective cohort study. BMJ. 2008;337:a439.

10. Goldstein ER, Ziegenfuss T, Kalman D, Kreider R, Campbell B, Wilborn C, et al. International society of sports nutrition position stand: caffeine and performance. J Int Soc Sports Nutr. 2010;7(1):5.

11. Astorino TA, Roberson DW. Efficacy of acute caffeine ingestion for short-term high-intensity exercise performance: a systematic review. J Strength Cond Res. 2010;24(1):257-65.

12. Warren GL, Park ND, Maresca RD, McKibans KI, Millard-Stafford ML. Effect of caffeine ingestion on muscular strength and endurance: a meta-analysis. Med Sci Sports Exerc. 2010;42(7):1375-87.

13. Astorino TA, Terzi MN, Roberson DW, Burnett TR. Effect of two doses of caffeine on muscular function during isokinetic exercise. Med Sci Sports Exerc. 2010;42(12):2205-10.

14. Bloms LP, Fitzgerald JS, Short MW, Whitehead JR. The Effects of Caffeine on Vertical Jump Height and Execution in Collegiate Athletes. J Strength Cond Res. 2016;30(7):1855-61.

15. Timmins TD, Saunders DH. Effect of caffeine ingestion on maximal voluntary contraction strength in upper- and lower-body muscle groups. J Strength Cond Res. 2014;28(11):3239-44.

16. Tallis J, Muhammad B, Islam M, Duncan MJ. Placebo effects of caffeine on maximal voluntary concentric force of the knee flexors and extensors. Muscle Nerve. 2016;54(3):479-86.

17. Beedie CJ, Foad AJ. The placebo effect in sports performance: a brief review. Sports Med. 2009;39(4):313-29.

18. Benedetti F. Placebo and the new physiology of the doctor-patient relationship. Physiol Rev. 2013;93(3):1207-46.

19. Trexler ET, Smith-Ryan AE, Roelofs EJ, Hirsch KR, Mock MG. Effects of coffee and caffeine anhydrous on strength and sprint performance. Eur J Sport Sci. 2016;16(6):702-10.

20. Behrens M, Mau-Moeller A, Heise S, Skripitz R, Bader R, Bruhn S. Alteration in neuromuscular function of the plantar flexors following caffeine ingestion: Caffeine and neuromuscular function. Scand J Med Sci Sports. 2015;25(1):e50-8.

21. Behrens M, Mau-Moeller A, Weippert M, Fuhrmann J, Wegner K, Skripitz R, et al. Caffeine-induced increase in voluntary activation and strength of the quadriceps muscle during isometric, concentric and eccentric contractions. Sci Rep. 2015;5:10209.

22. Diaz-Lara FJ, Del Coso J, García JM, Portillo LJ, Areces F, Abián-Vicén J. Caffeine improves muscular performance in elite Brazilian Jiu-jitsu athletes. Eur J Sport Sci. 2016;16(8):1079-86.

23. Duncan MJ, Thake CD, Downs PJ. Effect of caffeine ingestion on torque and muscle activity during resistance exercise in men. Muscle Nerve. 2014;50(4):523-7.

24. Mora-Rodríguez R, García Pallarés J, López-Samanes Á, Ortega JF, Fernández-Elías VE. Caffeine ingestion reverses the circadian rhythm effects on neuromuscular performance in highly resistance-trained men. PloS One. 2012;7(4):e33807

25. Razali NM, Wah YB. Power comparisons of Shapiro-Wilk, Kolmogorov-Smirnov, Lilliefors and AndersonDarling tests. J Stat Model Anal. 2011;2(1):21-33.

26. Bazzucchi I, Felici F, Montini M, Figura F, Sacchetti M. Caffeine improves neuromuscular function during maximal dynamic exercise. Muscle Nerve. 2011;43(6):839-44

27. Black CD, Waddell DE, Gonglach AR. Caffeine's Ergogenic Effects on Cycling: Neuromuscular and Perceptual Factors. Med Sci Sports Exerc. 2015;47(6):1145-58.

28. Chen H-Y, Wang H-S, Tung K, Chao H-H. Effects of Gender Difference and Caffeine Supplementation on Anaerobic Muscle Performance. Int J Sports Med. 2015;36(12):974-8.

29. Fimland MS, Helgerud J, Knutsen A, Ruth H, Leivseth G, Hoff J. No effect of prior caffeine ingestion on neuromuscular recovery after maximal fatiguing contractions. Eur J Appl Physiol. 2010;108(1):123-30.

30. Trevino MA, Coburn JW, Brown LE, Judelson DA, Malek MH. Acute effects of caffeine on strength and muscle activation of the elbow flexors. J Strength Cond Res. 2015;29(2):513-20.

31. Goldstein E, Jacobs PL, Whitehurst M, Penhollow T, Antonio J. Caffeine enhances upper body strength in resistance-trained women. J Int Soc Sports Nutr. 2010;7:18
32. Shield A, Zhou S. Assessing voluntary muscle activation with the twitch interpolation technique. Sports Med AuckI NZ. 2004;34(4):253-67.

33. 33. Gabriel DA, Kamen G, Frost G. Neural adaptations to resistive exercise: mechanisms and recommendations for training practices. Sports Med. 2006;36(2):133-49.

34. Mizuno M, Kimura Y, Tokizawa K, Ishii K, Oda K, Sasaki T, et al. Greater adenosine A(2A) receptor densities in cardiac and skeletal muscle in endurance-trained men: a [11C]TMSX PET study. Nucl Med Biol. 2005;32(8):831-6.

35. Mohr T, Van Soeren M, Graham TE, Kjaer M. Caffeine ingestion and metabolic responses of tetraplegic humans during electrical cycling. J Appl Physiol. 1998;85(3):979-85.

36. Tarnopolsky M, Cupido C. Caffeine potentiates low frequency skeletal muscle force in habitual and nonhabitual caffeine consumers. J Appl Physiol. 2000;89(5):1719-24.

37. Tallis J, Duncan MJ, James RS. What can isolated skeletal muscle experiments tell us about the effects of caffeine on exercise performance? Br J Pharmacol. 2015;172(15):3703-13.

38. Kalmar JM. The influence of caffeine on voluntary muscle activation. Med Sci Sports Exerc 2005:37(12):2113-9.

39. Tallis J, James RS, Cox VM, Duncan MJ. The effect of physiological concentrations of caffeine on the power output of maximally and submaximally stimulated mouse EDL (fast) and soleus (slow) muscle. J Appl Physiol. 2012;1 12(1):64-71.

40. Lindinger MI, Willmets RG, Hawke TJ. Stimulation of $\mathrm{Na}+, \mathrm{K}(+)$-pump activity in skeletal muscle by methylxanthines: evidence and proposed mechanisms. Acta Physiol Scand. 1996;156(3):347-53.

41. Pearce J, Norton LE, Senchina DS, Spriet LL, Burke LM, Stear SJ, et al. A-Z of nutritional supplements: dietary supplements, sports nutrition foods and ergogenic aids for health and performance-Part 37. Br J Sports Med. 2012;46(13):954-6.

42. Bell DG, McLellan TM. Exercise endurance 1, 3, and $6 \mathrm{~h}$ after caffeine ingestion in caffeine users and nonusers. J Appl Physiol. 2002;93(4):1227-34.

43. Attwood AS, Higgs S, Terry P. Differential responsiveness to caffeine and perceived effects of caffeine in moderate and high regular caffeine consumers. Psychopharmacology (Berl.). 2007;190(4):469-77.

44. Cornelis MC, El-Sohemy A, Campos H. Genetic polymorphism of the adenosine A2A receptor is associated with habitual caffeine consumption. Am J Clin Nutr. 2007;86(1):240-4.

45. Skinner TL, Jenkins DG, Folling J, Leveritt MD, Coombes JS, Taaffe DR. Influence of carbohydrate on serum caffeine concentrations following caffeine ingestion. J Sci Med Sport. 2013;16(4):343-7.

46. Mora-Rodríguez R, Pallarés JG, López-Gullón JM, López-Samanes Á, Fernández-Elías VE, Ortega JF. Improvements on neuromuscular performance with caffeine ingestion depend on the time-of-day. J Sci Med Sport. 2015;18(3):338-42.

47. Pallarés JG, Fernández-Elías VE, Ortega JF, Muñoz G, Muñoz-Guerra J, Mora-Rodríguez R. Neuromuscular responses to incremental caffeine doses: performance and side effects. Med Sci Sports Exerc. 2013;45(11):2184-92.

48. Skinner TL, Jenkins DG, Taaffe DR, Leveritt MD, Coombes JS. Coinciding exercise with peak serum caffeine does not improve cycling performance. J Sci Med Sport. 2013;16(1):54-9.

49. Cornelis MC, El-Sohemy A, Kabagambe EK, Campos H. Coffee, CYP1A2 genotype, and risk of myocardial infarction. JAMA. 2006;295(10):1135-41.

50. Palatini P, Ceolotto G, Ragazzo F, Dorigatti F, Saladini F, Papparella I, et al. CYP1A2 genotype modifies the association between coffee intake and the risk of hypertension. J Hypertens. 2009;27(8):1594-601.

51. 51. Meyers BM, Cafarelli E. Caffeine increases time to fatigue by maintaining force and not by altering firing rates during submaximal isometric contractions. J Appl Physiol. 2005;99(3):1056-63.

52. Pataky MW, Womack CJ, Saunders MJ, Goffe JL, D'Lugos AC, El-Sohemy A, et al. Caffeine and 3-km cycling performance: Effects of mouth rinsing, genotype, and time of day. Scand J Med Sci Sports. 2016;26(6):613-9.

53. Womack CJ, Saunders MJ, Bechtel MK, Bolton DJ, Martin M, Luden ND, et al. The influence of a CYP1A2 polymorphism on the ergogenic effects of caffeine. J Int Soc Sports Nutr. 2012;9(1):7.

54. Beedie CJ, Stuart EM, Coleman DA, Foad AJ. Placebo effects of caffeine on cycling performance. Med Sci Sports Exerc. 2006;38(12):2159-64

55. Beedie CJ, Foad AJ, Coleman DA. Identification of placebo responsive participants in $40 \mathrm{~km}$ laboratory cycling performance. J Sports Sci Med. 2008;7(1):166-75.

56. Foad AJ, Beedie CJ, Coleman DA. Pharmacological and psychological effects of caffeine ingestion in 40-km cycling performance. Med Sci Sports Exerc. 2008;40(1):158-65.

57. Duncan MJ, Lyons M, Hankey J. Placebo effects of caffeine on short-term resistance exercise to failure. Int J Sports Physiol. Perform. 2009;4(2):244-53.

58. Pollo A, Carlino E, Benedetti F. The top-down influence of ergogenic placebos on muscle work and fatigue. Eur J Neurosci. 2008;28(2):379-88.

59. International Olympic Comitee. London 2012 105kg heavyweight men - Olympic Weightlifting. Int Olymp Com OffWebsite. 2016 Jul 20 [accessed 2016 Jul 20]. https://www.olympic.org/london-2012/ weightlifting $/ 105 \mathrm{~kg}$-heavyweight-men 